\title{
Mass Spectra of Thermal Degradation Products of Polymers
}

\author{
Paul Bradt and Fred L. Mohler
}

\begin{abstract}
Polymers are degraded or evaporated from a tube furnace directly into the mass spectrometer, and mass spectra recorded as the temperature of the sample is increased. Polyethylene degrades into paraffins, olefins, and diolefins and at $386^{\circ} \mathrm{C}$ the mass spectrum extends to mass $684, \mathrm{C}_{49} \mathrm{H}_{96}$. Polyvinyl chloride degrades in two stages. From $127^{\circ}$ to $300^{\circ} \mathrm{C}$ it loses $\mathrm{HCl}$ and some benzene, and above $300^{\circ} \mathrm{C}$ it evolves a great variety of hydrocarbons.

The heavy fraction from rubber degradation evaporates over a wide temperature range, and molecules containing from 3 to 16 units of the monomer, $\mathrm{C}_{5} \mathrm{H}_{8}$, are recorded. The heaviest ion is $\mathrm{C}_{80} \mathrm{H}_{127}$ of mass 1,087. Degradation of polyxylylene gives molecules containing from 1 to 9 units of the monomer, $\mathrm{C}_{8} \mathrm{H}_{8}$, the heaviest ion being $\mathrm{C}_{72} \mathrm{H}_{71}$ of mass 935 . A low polymer of polyphenyl was evaporated and molecules containing 2 to 11 monomer units were recorded. The heaviest ion was $\mathrm{C}_{66} \mathrm{H}_{46}$ of mass 838 .
\end{abstract}

\section{Introduction}

The products of thermal degradation of polymers have been a subject of systematic research by S. L. Madorsky $[1,2,3]^{1}$ and his colleagues in the NBS Polymer Structure Section. In Madorsky's risearches the volatile products of thermal degradition have been analyzed by mass spectrometer, and in most cases the average mclecular weight of the nonvolatile degradation product has been evaluated by standard methods. In a few instances, notably polymethylmethacrylate and polytetrafluoroethylene, the degradation product is almost pure monomer, and these techniques give a complete description of the degradation product. In most cases the nonvolatile fraction is an appreciable part of the degradation product, and existing information on this is fragmentary and incomplete.

In a previous publication by the authors [4] on polystyrene degradation, a technique is described for degrading and evaporating the products of degradation directly into the ionization chamber of a mass spectrometer and recording mass spectra of all the products that are volatile at the temperature of degradation. The same technique has been applied to record the mass spectra of molecules of perfluoropolyphenyl, which evaporates without degradation [5].

The present paper gives a survey of mass spectra obtained when various other polymers are evaporated or degraded directly into the mass spectrometer.

\section{Experimental Method}

A small tube furnace extends to the entrance port in the ionization chamber of a mass spectrometer, and the sample to be studied is in a short length of capillary tubing supported in the tube furnace by a thermocouple, which measures the temperature of the sample. The amount of sample is of the order of $1 \mathrm{mg}$. The mass spectrometer is a Nier-type $60^{\circ}$ instrument of 6 -in. radius of curvature, and the spectrum is recorded with a pen recorder by varying the magnetic field. The mass scale can be extended

\footnotetext{
Figures in brackets indicate the literature refrences at the end of this paper.
}

as required by lowering the ion-accelerating voltage, which is normally 2,500 for molecular weights less than 300. The resolving power is about 1 in 300 , which does not resolve unit mass in the high mass range encountered in these studies. Partial resolution sufficient to identify individual ions of hydrocarbons extended to about mass 600 . Ion currents are expressed in arbitrary units of scale divisions on the record at the maximum sensitivity used in each series of measurements.

In each experiment, after obtaining a good vacuum, the temperature was increased step by step, and at each step the mass spectrum was recorded. It required about $2 \mathrm{hr}$ to cover the full range of spectrum at optimum recording speed. A higher speed was often used for a quick survey to see whether there was anything to measure. Each experiment extended over several days, and after the sample was exhausted the ionization chamber was dismantled and thoroughly cleaned.

\section{Results}

\subsection{Polymethylene}

A pure grade of polymethylene, made by decomposing diazomethane in the presence of a catalyst, was supplied by the Polymer Structure Section. This polymer is similar to polyethylene, except that there should be no branched hydrocarbon chains. Madorsky and Straus [3] find that this degrades by breaking at random $\mathrm{C}-\mathrm{C}$ bonds to give $n$-paraffins, 1- $n$-olefins, and diolefins. About 97 percent of the degradation product is not volatile at room temperature and has an average molecular weight of 692 , corresponding to about 50 carbon atoms.

The sample of polymethylene began to degrade into volatile compounds at about $335^{\circ} \mathrm{C}$. At $352^{\circ}$ $\mathrm{C}$ the hydrocarbon spectrum extended to mass 253 , $\mathrm{C}_{18} \mathrm{H}_{37}$. The maximum peak was 179 scale divisions. At $369^{\circ} \mathrm{C}$ the ion currents were much larger but unsteady because of bubble formation. The mass spectrum extended to $460, \mathrm{C}_{33} \mathrm{H}_{64}$. As the sample became depleted the ion current became steady and at $386^{\circ} \mathrm{C}$ the heaviest ions appeared. Table 1 gives some of the larger peaks in this spectrum, 
TABLE 1. Mass spectrum of degradation products of polymethylene at $386^{\circ} \mathrm{C}$

\begin{tabular}{|c|c|c|}
\hline$m / e$ & Ion & $\begin{array}{l}\text { Relative } \\
\text { abundance }\end{array}$ \\
\hline $\begin{array}{l}43 \\
57 \\
71 \\
83 \\
85\end{array}$ & $\begin{array}{l}\mathrm{C}_{3} \mathrm{H}_{7} \\
\mathrm{C}_{4} \mathrm{H}_{9} \\
\mathrm{C}_{5} \mathrm{H}_{11} \\
\mathrm{C}_{6} \mathrm{H}_{11} \\
\mathrm{C}_{6} \mathrm{H}_{13}\end{array}$ & $\begin{array}{r}65 \\
100 \\
66 \\
57 \\
48\end{array}$ \\
\hline $\begin{array}{r}97 \\
111 \\
125 \\
139 \\
141\end{array}$ & $\begin{array}{l}\mathrm{C}_{7} \mathrm{H}_{13} \\
\mathrm{C}_{8} \mathrm{H}_{15} \\
\mathrm{C}_{9} \mathrm{H}_{17} \\
\mathrm{C}_{10} \mathrm{H}_{19} \\
\mathrm{C}_{10} \mathrm{H}_{21}\end{array}$ & $\begin{array}{l}90 \\
53 \\
25 \\
7.0 \\
12\end{array}$ \\
\hline $\begin{array}{l}155 \\
169 \\
183 \\
197 \\
211\end{array}$ & $\begin{array}{l}\mathrm{C}_{11} \mathrm{H}_{23} \\
\mathrm{C}_{12} \mathrm{H}_{25} \\
\mathrm{C}_{13} \mathrm{H}_{27} \\
\mathrm{C}_{14} \mathrm{H}_{29} \\
\mathrm{C}_{15} \mathrm{H}_{31}\end{array}$ & $\begin{array}{l}8.0 \\
7.5 \\
7.0 \\
7.0 \\
5.5\end{array}$ \\
\hline $\begin{array}{l}225 \\
239 \\
253 \\
267 \\
281\end{array}$ & $\begin{array}{l}\mathrm{C}_{16} \mathrm{H}_{33} \\
\mathrm{C}_{17} \mathrm{H}_{35} \\
\mathrm{C}_{18} \mathrm{H}_{37} \\
\mathrm{C}_{19} \mathrm{H}_{39} \\
\mathrm{C}_{20} \mathrm{H}_{41}\end{array}$ & $\begin{array}{l}4.5 \\
5.5 \\
3.5 \\
4.0 \\
2.5\end{array}$ \\
\hline $\begin{array}{l}295 \\
306 \\
309 \\
320 \\
323\end{array}$ & $\begin{array}{l}\mathrm{C}_{21} \mathrm{H}_{43} \\
\mathrm{C}_{22} \mathrm{H}_{42} \\
\mathrm{C}_{22} \mathrm{H}_{45} \\
\mathrm{C}_{23} \mathrm{H}_{44} \\
\mathrm{C}_{23} \mathrm{H}_{47}\end{array}$ & $\begin{array}{l}3.0 \\
2.5 \\
2.5 \\
3.0 \\
2.5\end{array}$ \\
\hline 334 & $\begin{array}{l}\mathrm{C}_{24} \mathrm{H}_{46} \\
\mathrm{C}_{n} \mathrm{H}_{2 n-2} \\
\quad \text { from } n=25 \\
\quad \text { to } n=45\end{array}$ & $\begin{array}{l}\text { 3. } 0 \\
\text { 3. } 0\end{array}$ \\
\hline $\begin{array}{l}642 \\
656 \\
670 \\
684 \\
698\end{array}$ & $\begin{array}{l}\mathrm{C}_{46} \mathrm{H}_{90} \\
\mathrm{C}_{47} \mathrm{H}_{92} \\
\mathrm{C}_{48} \mathrm{H}_{94} \\
\mathrm{C}_{49} \mathrm{H}_{96} \\
\mathrm{C}_{50} \mathrm{H}_{95}\end{array}$ & $\begin{array}{r}3.0 \\
2.0 \\
1.5 \\
1.5 \\
<0.2\end{array}$ \\
\hline
\end{tabular}

which extended to mass $684, \mathrm{C}_{49} \mathrm{H}_{96}$. The maximum peak, at mass 57, was 103 scale divisions.

The mass spectrum of table 1 shows a remarkably regular succession of peaks at intervals of 14 mass units from mass 253 to mass 684 . For ions containing less than 22 carbon atoms the larger peaks in each carbon group are, with a few exceptions, the alkyl ions $\mathrm{C}_{n} \mathrm{H}_{2 n+1}^{+}$. In ions with more than 22 carbon atoms the ions $\mathrm{C}_{n} \mathrm{H}_{2 n-2}^{+}$become larger. The latter come presumably from the diolefin spectra. The spectra gave no evidence as to the mass distribution in the degradation products except that there are molecules with 49 or 50 carbon atoms.

The spectrum of table 1 was obtained from a sample that was nearly exhausted and this spectrum differs from the preceding spectrum at $369^{\circ} \mathrm{C}$ in the relative intensity of the pair of peaks $\mathrm{C}_{n} \mathrm{H}_{2 n-2}$ and $\mathrm{C}_{n} \mathrm{H}_{2 n+1}$ in each carbon group. The $2 n-2$ peak is larger in the spectrum at $386^{\circ} \mathrm{C}$, and the difference becomes conspicuous at the heavy end of the spectrum. This indicates that the polymethylene becomes depleted in hydrogen in the process of degradation.

\subsection{Polyvinyl Chloride}

A sample of polyvinyl chloride, "Geon 101", was supplied by the Bureau's Plastics Section. Polyvinyl chloride degrades in a complicated manner. At low temperatures evolution of $\mathrm{HCl}$ by the
TABLE 2. Summary of mass spectra of degradation products of polyvinyl chloride

\begin{tabular}{|c|c|c|c|c|}
\hline \multicolumn{5}{|c|}{ Ion currents in scale divisions } \\
\hline $\begin{array}{l}\text { Tempera- } \\
\text { ture }{ }^{\circ} \mathrm{C}\end{array}$ & $\mathrm{HCl}(m=36)$ & $\begin{array}{c}\text { Benzene } \\
(m=78)\end{array}$ & $\mathrm{C}_{7} \mathrm{H}_{7}(m=91)$ & $\underset{(m / e)}{\operatorname{Maximum}}$ \\
\hline $\begin{array}{l}127 \\
179 \\
194 \\
220 \\
220\end{array}$ & $\begin{array}{r}7 \\
218 \\
440 \\
2,300 \\
915\end{array}$ & $\begin{array}{r}12.5 \\
49.0 \\
244.0 \\
66.0\end{array}$ & $\begin{array}{l}4 \\
2\end{array}$ & $\begin{array}{l}128 \\
179 \\
179\end{array}$ \\
\hline \multicolumn{5}{|c|}{ Overnight at $217^{\circ} \mathrm{C}$} \\
\hline $\begin{array}{l}250 \\
280 \\
306 \\
335\end{array}$ & $\begin{array}{r}1,015 \\
1,290 \\
126 \\
59\end{array}$ & $\begin{array}{l}45.0 \\
43.0 \\
51.0 \\
37.0\end{array}$ & $\begin{array}{r}13 \\
72 \\
123\end{array}$ & $\begin{array}{l}179 \\
192 \\
253\end{array}$ \\
\hline \multicolumn{5}{|c|}{ Overnight at $320^{\circ} \mathrm{C}$} \\
\hline $\begin{array}{l}368 \\
389\end{array}$ & $\begin{array}{l}15 \\
3.5\end{array}$ & $\begin{array}{l}40.0 \\
11.5\end{array}$ & $\begin{array}{r}250 \\
89\end{array}$ & $\begin{array}{l}520 \\
596\end{array}$ \\
\hline
\end{tabular}

following reaction is predominant:

$\underset{\mathrm{H}}{\stackrel{\mathrm{C}}{\mathrm{C}}} \stackrel{\mathrm{Cl}}{\mathrm{C}}-\stackrel{\mathrm{H}}{\mathrm{H}}-\stackrel{\mathrm{C}}{\mathrm{C}}-\stackrel{\mathrm{C}}{\mathrm{C}}-\rightarrow-\mathrm{CH}=\mathrm{CH}-\mathrm{CH}=\mathrm{CH}-\ldots .+n \mathrm{HCl}$.

Some benzene is also evolved in this temperature range. At temperatures above $300^{\circ} \mathrm{C}$ the $\mathrm{CH}$ chain degrades to give a mixture of hydrocarbons.

Table 2 lists the series of spectra obtained in one experiment in the range $127^{\circ}$ to $389^{\circ} \mathrm{C}$. It includes molecule ion peaks of $\mathrm{HCl}$ and benzene and the benzyl radical, and in the last column lists the heaviest ion recorded in each spectrum. Peak heights are given in scale divisions.

The evolution of $\mathrm{HCl}$ began at about $127^{\circ} \mathrm{C}$, and at $220^{\circ} \mathrm{C}$ the rate of evolution of gas reached the maximum amount for satisfactory measurement. The sample was held overnight near this temperature, and then the temperature was slowly increased. Above $300^{\circ} \mathrm{C}$ the evolution of $\mathrm{HCl}$ and benzene became small and a complicated hydrocarbon spectrum appeared. The maximum peak in this spectrum was the benzyl radical ion of mass 91. Above $389^{\circ} \mathrm{C}$ the evolution of vapor decreased and a carbonized residue was left in the sample tube.

Table 3 gives the larger peaks in the mass spectra obtained at four temperatures. Below $300^{\circ} \mathrm{C}$ benzene is by far the most abundant hydrocarbon. The small peaks extending to mass 179 are heavier aromatics. The largest of these, at mass 128 , is the molecule ion of naphthalene. The peak at mass 178 may be the molecule ion of anthracene, but peaks at 179 and 167 come from something else. At the highest temperature there are peaks at every mass number above 78 , and beyond mass 200 all peaks become of the same order of magnitude. From mass 400 to mass 596 the spectrum of the partially resolved peaks appears as a very uniform sine wave with maxima at even mass numbers. The upper limit is set by resolving power, and the ion current is measurable beyond mass 596 . 
TABLE 3. Partial mass spectrum of degradation products of polyvinyl chloride

\begin{tabular}{|c|c|c|c|c|c|}
\hline \multirow{2}{*}{$m / e$} & \multirow{2}{*}{ Ion } & \multicolumn{4}{|c|}{ Ion currents in scale divisions } \\
\hline & & $220^{\circ} \mathrm{C}$ & $306^{\circ} \mathrm{C}$ & $335^{\circ} \mathrm{C}$ & $389^{\circ} \mathrm{C}$ \\
\hline $\begin{array}{l}36 \\
78 \\
79 \\
89 \\
91\end{array}$ & $\begin{array}{l}\mathrm{HCl} \\
\mathrm{C}_{6} \mathrm{H}_{6} \\
\mathrm{C}_{6} \mathrm{H}_{7} \\
\mathrm{C}_{6} \mathrm{H}_{9} \\
\mathrm{C}_{7} \mathrm{H}_{7}\end{array}$ & $\begin{array}{c}2,294 \\
244 \\
4\end{array}$ & $\begin{array}{r}126 \\
51 \\
22 \\
-\quad 72\end{array}$ & $\begin{array}{c}59 \\
37 \\
36 \\
-123.0\end{array}$ & $\begin{array}{l}3.5 \\
11.5 \\
37 \\
35 \\
89\end{array}$ \\
\hline $\begin{array}{r}93 \\
95 \\
104 \\
105 \\
115\end{array}$ & $\begin{array}{l}\mathrm{C}_{7} \mathrm{H}_{9} \\
\mathrm{C}_{7} \mathrm{H}_{11} \\
\mathrm{C}_{8} \mathrm{H}_{8} \\
\mathrm{C}_{8} \mathrm{H}_{9} \\
\mathrm{C}_{9} \mathrm{H}_{7}\end{array}$ & $\begin{array}{r}1.0 \\
6.5\end{array}$ & $\begin{array}{l}16 \\
12 \\
36\end{array}$ & $\begin{array}{l}18.0 \\
31 \\
37 \\
75\end{array}$ & $\begin{array}{c}25 \\
25 \\
9 \\
55.0 \\
40.0\end{array}$ \\
\hline $\begin{array}{l}117 \\
119 \\
128 \\
129 \\
131\end{array}$ & $\begin{array}{l}\mathrm{C}_{9} \mathrm{H}_{9} \\
\mathrm{C}_{9} \mathrm{H}_{11} \\
\mathrm{C}_{10} \mathrm{H}_{8} \\
\mathrm{C}_{10} \mathrm{H}_{9} \\
\mathrm{C}_{10} \mathrm{H}_{11}\end{array}$ & $\begin{array}{r}3.5 \\
2.0 \\
14 \\
4.5\end{array}$ & $\begin{array}{l}22.5 \\
40 \\
24\end{array}$ & $\begin{array}{l}51 \\
11 \\
67 \\
57 \\
20\end{array}$ & $\begin{array}{l}21.0 \\
21.0 \\
21.0 \\
49 \\
38\end{array}$ \\
\hline $\begin{array}{l}141 \\
143 \\
152 \\
153 \\
154\end{array}$ & $\begin{array}{l}\mathrm{C}_{11} \mathrm{H}_{9} \\
\mathrm{C}_{11} \mathrm{H}_{11} \\
\mathrm{C}_{12} \mathrm{H}_{8} \\
\mathrm{C}_{12} \mathrm{H}_{9} \\
\mathrm{C}_{12} \mathrm{H}_{10}\end{array}$ & $\begin{array}{l}4.0 \\
1.7 \\
1.7 \\
1.5\end{array}$ & $\begin{array}{r}22.5 \\
6.0 \\
10.0 \\
10.0 \\
13.0\end{array}$ & $\begin{array}{l}54 \\
38 \\
24 \\
24 \\
18\end{array}$ & $\begin{array}{l}46.0 \\
33.0 \\
21.0 \\
22.0 \\
12.0\end{array}$ \\
\hline $\begin{array}{l}155 \\
165 \\
167 \\
178 \\
179\end{array}$ & $\begin{array}{l}\mathrm{C}_{12} \mathrm{H}_{11} \\
\mathrm{C}_{13} \mathrm{H}_{9} \\
\mathrm{C}_{13} \mathrm{H}_{11} \\
\mathrm{C}_{14} \mathrm{H}_{10} \\
\mathrm{C}_{14} \mathrm{H}_{11}\end{array}$ & $\begin{array}{l}3.5 \\
2.0 \\
3.5 \\
2.5\end{array}$ & $\begin{array}{r}5.5 \\
15 \\
10.5 \\
10.5 \\
6.0\end{array}$ & $\begin{array}{c}20 \\
45 \\
28 \\
9.0 \\
26.0\end{array}$ & $\begin{array}{l}38 \\
47.0 \\
35 \\
31 \\
41\end{array}$ \\
\hline $\begin{array}{l}191 \\
193 \\
203 \\
215 \\
229\end{array}$ & $\begin{array}{l}\mathrm{C}_{15} \mathrm{H}_{11} \\
\mathrm{C}_{15} \mathrm{H}_{13} \\
\mathrm{C}_{16} \mathrm{H}_{11} \\
\mathrm{C}_{17} \mathrm{H}_{11} \\
\mathrm{C}_{18} \mathrm{H}_{13}\end{array}$ & & $\begin{array}{r}2.5 \\
3.0 \\
\end{array}$ & $\begin{array}{l}13.5 \\
12.0 \\
10 \\
14 \\
5\end{array}$ & $\begin{array}{l}28 \\
22 \\
28 \\
36 \\
32\end{array}$ \\
\hline $\begin{array}{c}239 \\
253 \\
254 \\
\text { to } \\
596\end{array}$ & $\begin{array}{l}\mathrm{C}_{19} \mathrm{H}_{11} \\
\mathrm{C}_{20} \mathrm{H}_{13}\end{array}$ & & & $\begin{array}{l}2.5 \\
2.0\end{array}$ & $\begin{array}{l}27 \\
27 \\
\text { (a) }\end{array}$ \\
\hline
\end{tabular}

${ }^{a} \mathrm{At} 389^{\circ} \mathrm{C}$ there are peaks of the same magnitude at every mass number.

\subsection{Crepe Rubber}

Crepe-rubber degradation has been studied by Straus and Madorsky [2]. The degradation products at $350^{\circ} \mathrm{C}$ are about 4 percent of monomer, 13 percent of dimer, and 83 percent of heavier compounds with an average molecular weight of 616 . The monomer is isoprene, 2-methyl-1,3-butadiene, of molecular weight 68 , and the maximum peak is at mass 67 . The dimer is mostly the cyclic compound dipentene, and the maximum peak is at mass 68 [8].

Crepe rubber degraded in the range $236^{\circ}$ to $353^{\circ} \mathrm{C}$. The mass spectrum extended to mass 271 and by comparison with the known mass spectra of the monomer and dimer, the product appeared to be monomer, dimer, trimer, and tetramer in roughly comparable amounts. The experiment was not entirely successful because the ion currents were small. Failure to find the heavy molecules reported by Straus and Madorsky [2] may be ascribed to inadequate sensitivity.

A sample of the heavy fraction of the degradation product with monomer and dimer removed was supplied by Straus. This was evaporated into the mass spectrometer and 25 mass spectra were recorded in the range $80^{\circ}$ to $460^{\circ} \mathrm{C}$. Table 4 gives some of the peaks in six of these mass spectra. These mass spectra are complicated, but, except for peaks at masses 69 and 81, the larger peaks come at intervals
TABLE 4. Partial mass spectrum of the heavy fraction obtained from rubber pyrolysis

\begin{tabular}{|c|c|c|c|c|c|c|c|}
\hline \multirow{2}{*}{$m / e$} & \multirow{2}{*}{ Ion } & \multicolumn{6}{|c|}{ Relative intensity at temperature of evaporation } \\
\hline & & $80^{\circ} \mathrm{C}$ & $130^{\circ} \mathrm{C}$ & $138^{\circ} \mathrm{C}$ & $209^{\circ} \mathrm{C}$ & $209^{\circ} \mathrm{C}$ & $264^{\circ} \mathrm{C}$ \\
\hline $\begin{array}{r}69 \\
81 \\
135 \\
203 \\
271\end{array}$ & $\begin{array}{l}\mathrm{C}_{5} \mathrm{H}_{9} \\
\mathrm{C}_{6} \mathrm{H}_{9} \\
\mathrm{C}_{10} \mathrm{H}_{15} \\
\mathrm{C}_{15} \mathrm{H}_{23} \\
\mathrm{C}_{20} \mathrm{H}_{31}\end{array}$ & $\begin{array}{r}70 \\
100 \\
41 \\
6\end{array}$ & $\begin{array}{c}60 \\
100 \\
65 \\
16 \\
5.3\end{array}$ & $\begin{array}{c}52 \\
100 \\
64 \\
15 \\
4.4\end{array}$ & $\begin{array}{l}53 \\
100 \\
100 \\
30 \\
12\end{array}$ & $\begin{array}{r}48 \\
100 \\
48 \\
13.5 \\
4.5\end{array}$ & $\begin{array}{c}100 \\
26 \\
14.5 \\
9.5\end{array}$ \\
\hline $\begin{array}{l}339 \\
407 \\
475 \\
543 \\
611\end{array}$ & $\begin{array}{l}\mathrm{C}_{25} \mathrm{H}_{39} \\
\mathrm{C}_{30} \mathrm{H}_{47} \\
\mathrm{C}_{35} \mathrm{H}_{55} \\
\mathrm{C}_{40} \mathrm{H}_{63} \\
\mathrm{C}_{45} \mathrm{H}_{71}\end{array}$ & $\begin{array}{c}\cdots \\
\cdots \cdots \\
\cdots \cdots \\
\cdots\end{array}$ & $\begin{array}{l}2.9 \\
2.5 \\
2.6 \\
\\
\end{array}$ & $\begin{array}{l}1.5 \\
2 \\
2 \\
2 \\
6.0\end{array}$ & $\begin{array}{l}9.0 \\
6.3 \\
2.3 \\
2.7 \\
7.5\end{array}$ & $\begin{array}{l}2.7 \\
2.1 \\
1.8 \\
1.5 \\
1.8\end{array}$ & $\begin{array}{l}5.5 \\
5.0 \\
4.0 \\
3.0 \\
2.8\end{array}$ \\
\hline $\begin{array}{l}679 \\
747 \\
815 \\
883 \\
951\end{array}$ & $\begin{array}{l}\mathrm{C}_{50} \mathrm{H}_{79} \\
\mathrm{C}_{55} \mathrm{H}_{87} \\
\mathrm{C}_{60} \mathrm{H}_{95} \\
\mathrm{C}_{65} \mathrm{H}_{103} \\
\mathrm{C}_{70} \mathrm{H}_{111}\end{array}$ & $\begin{array}{c}\ldots . \\
\cdots \cdots \\
\cdots \cdots \\
\cdots\end{array}$ & $\begin{array}{c}\ldots . \\
\cdots \\
\cdots \\
\cdots\end{array}$ & \begin{tabular}{c}
3.0 \\
\hdashline- \\
$\cdots$
\end{tabular} & $\begin{array}{c}12.0 \\
2.7 \\
0.25 \\
\end{array}$ & $\begin{array}{r}2.3 \\
5.1 \\
8.6 \\
2.3 \\
-. .\end{array}$ & $\begin{array}{l}1.8 \\
2.2 \\
2.5 \\
2.7 \\
2.5\end{array}$ \\
\hline $\begin{array}{l}1,019 \\
1,087 \\
\text { Scale } \\
\text { mas: }\end{array}$ & $\begin{array}{l}\begin{array}{c}\mathrm{C}_{75} \mathrm{H}_{119} \\
\mathrm{C}_{80} \mathrm{H}_{127} \\
\text { isions at }\end{array}\end{array}$ & $\begin{array}{l}\ldots \\
150\end{array}$ & $\begin{array}{c}\ldots \\
738 \\
\cdots\end{array}$ & $\begin{array}{l}\cdots \\
59\end{array}$ & 696 & $\begin{array}{c}\ldots \\
656\end{array}$ & $\begin{array}{r}0.6 \\
.4\end{array}$ \\
\hline
\end{tabular}

of 68 mass units, and have masses one unit less than the molecular weight of polvmers of isoprene. Table 4 gives the abundances of these peaks relative to the mass 81 peak. The last row of table 4 gives the height of the 81 peak in scale divisions. This is a measure of the rate of evaporation.

At $80^{\circ} \mathrm{C}$ the vapor is mostly trimer. The peaks at masses 69,81 , and 135 are present but are relatively small in the dimer spectrum and must come primarily from ionization of the trimer. At $130^{\circ} \mathrm{C}$ the rate of evaporation is high, and molecules with 4, 5, 6, and 7 monomer units appear. After these evaporate, molecules with 8,9 , and 10 units appear. At $209^{\circ} \mathrm{C}$ there is rapid evaporation of molecules with 10 monomer units. These quickly evaporate and in the next spectrum record, molecules with 11, 12 , and 13 units appear. The heaviest ions were recorded at $264^{\circ} \mathrm{C}$. Peaks at 1,019 and 1,087 are barely visible and could possibly be accidental fluctuations. A comparison with the experiment on rubber degradation indicates that at $264^{\circ} \mathrm{C}$ there may be some thermal degradation of the sample, but at the lower temperatures this is negligible. The larger peaks in the lower molecular weight range must come almost entirely from ionization of the heavier molecules.

\subsection{Polyxylylene}

An experimental polymer, polyparaxylylene, $\mathrm{CH}_{2}-\mathrm{C}_{6} \mathrm{H}_{4}-\mathrm{CH}_{2}-\mathrm{CH}_{2}-\mathrm{C}_{6} \mathrm{H}_{4}-\mathrm{CH}_{2} \ldots$. . was supplied by the Polaroid Corporation. 'Experiments by Madorsky and Straus [6] showed that about 4 percent of the degradation product was volatile at room temperature and the heavy fraction had an average molecular weight of 661. Mass-spectrometer analysis of the volatile fraction gave 78 mole percent of xylene, 7 percent of methylethylbenzene, 4 percent of methylstyrene, 8 percent of toluene, and 3 percent of benzene.

When this polymer was degraded directly into the 
TABLE 5. Partial mass spectrum of degradation products of polyxylylene at $310^{\circ} \mathrm{C}$.

\begin{tabular}{|c|c|c|}
\hline Mass & Ion ${ }^{a}$ & $\begin{array}{l}\text { Relative } \\
\text { intensity }\end{array}$ \\
\hline $\begin{array}{l}104 \\
105 \\
207 \\
209 \\
311\end{array}$ & $\begin{array}{c}\mathrm{X} \\
\mathrm{X}+1 \\
2 \mathrm{X}-1 \\
2 \mathrm{X}+1 \\
3 \mathrm{X}-1\end{array}$ & $\begin{array}{r}135 \\
1,000 \\
334 \\
204 \\
84\end{array}$ \\
\hline $\begin{array}{l}313 \\
415 \\
417 \\
519 \\
521\end{array}$ & $\begin{array}{l}3 \mathrm{X}+1 \\
4 \mathrm{X}-1 \\
4 \mathrm{X}+1 \\
5 \mathrm{X}-1 \\
5 \mathrm{X}+1\end{array}$ & $\begin{array}{l}42 \\
22 \\
19 \\
19 \\
19\end{array}$ \\
\hline $\begin{array}{l}623 \\
727 \\
831 \\
935\end{array}$ & $\begin{array}{l}6 \mathrm{X}-1 \\
7 \mathrm{X}-1 \\
8 \mathrm{X}-1 \\
9 \mathrm{X}-1\end{array}$ & $\begin{array}{l}24 \\
20 \\
10 \\
0.7\end{array}$ \\
\hline
\end{tabular}

\& $\mathrm{X}$ denotes the monomer unit $\mathrm{CH}_{2} \cdot \mathrm{C}_{6} \mathrm{H}_{4} \cdot \mathrm{CH}_{2}$ of mass 104.

mass spectrometer it gave a complicated but repetitive mass-spectrum pattern extending to mass 935 . Table 5 gives the larger peaks in the spectrum obtained at $310^{\circ} \mathrm{C}$. These peaks come at multiples of $104 \pm 1$ mass units. That is, the larger peaks fall at odd mass numbers. The xylene molecule ion of mass 106 is small, but xylene amounts to only 3 percent of the degradation products [6]. The large peak at mass 105 must come from the ionization of heavier molecules. The complete spectrum includes other less abundant ions with 1 or $2 \mathrm{CH}_{2}$ radicals added to or subtracted from the chain of xylylene units. Evidently the polymer breaks preferentially at the beta bond between the two $\mathrm{CH}_{2}$ radicals, but it can also break at the alpha bonds.

\subsection{Polyphenyl}

The polyphenyl was an experimental polymer synthesized by Max Hellmann of the NBS Polymer Structure Section from diiodobiphenyl heated in contact with copper. The product was partially soluble in benzene, and the lighter soluble fraction was estimated to have a mean molecular weight of 1,460 , corresponding to 19 phenyl rings in each chain. The molecular weight of the insoluble fraction is unknown but is presumably much heavier than this.

When the insoluble fraction was slowly heated in the mass spectrometer to $500^{\circ} \mathrm{C}$, only small impurity peaks were observed. The hydrogen mass range was not covered in any of these experiments. When the sample was removed it appeared to be completely carbonized. Apparently polyphenyl degrades by losing hydrogen atoms and not by breaking into smaller polyphenyl chains.

The soluble fraction of polyphenyl gave the results shown in table 6. Peak heights are given in scale divisions and many small peaks are omitted. The mass range below 230 was not covered in spectra obtained at $195^{\circ} \mathrm{C}$ and at $230^{\circ} \mathrm{C}$. At the lowest temperature the sample gave off large amounts of unpolymerized biphenyl. (The ion of mass 163 is unidentified.) With increasing temperature heavier molecules appeared, but ion currents were always
TABLE 6. Mass spectra of the soluble fraction of polyphenyl

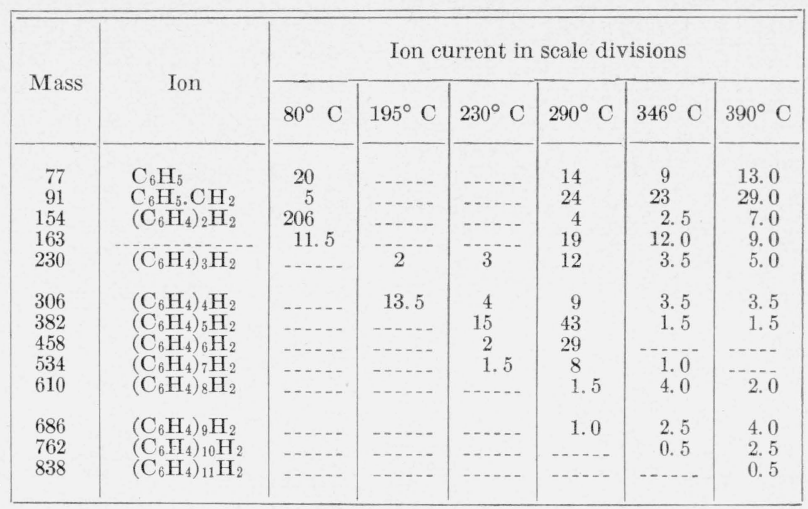

relatively small. At $195^{\circ} \mathrm{C}$, molecules with 4 phenyl rings are predominant, and at $230^{\circ} \mathrm{C}$, molecules with 5 rings are most abundant, and the 4 ring molecules are diminished. At $346^{\circ} \mathrm{C}$ and at $390^{\circ} \mathrm{C}$ increasingly heavier molecules appear, but at the higher temperature rapid carbonization terminates the evaporation.

\section{Summary and Conclusions}

The experimental results with polyethylene are consistent with previous work on polyethylene degradation, except that the upper mass limit 684 of table 1 is somewhat less than expected. The average molecular weight of the heavy fraction had been estimated as 690 .

Results on degradation of polyvinyl chloride should clarify existing uncertainty as to the mechanism of degradation [7]. There are two distinct stages in the degradation, with loss of $\mathrm{HCl}$ and benzene predominant at low temperatures and random breaking of the resulting $\mathrm{CH}$ chain occurring above $300^{\circ} \mathrm{C}$. The $\mathrm{CH}$ chain evidently degrades in a complicated manner above $300^{\circ} \mathrm{C}$, taking up hydrogen atoms from the residue to form hydrocarbons with all degrees of saturation. There is no evidence of evaporation of chlorinated hvdrncarbons.

The experiment on direct degradation of crepe rubber gave a range of molecular weights much smaller than expected, but this may be ascribed to inadequate sensitivity. The experiment on evaporation of the heavy fraction recovered from rubber degradation showed a range of molecular weights consistent with previous estimates. There are molecules ranging in molecular weight from 204 (3 monomer units) to 1,088 (16 units) and molecules with $9,10,11$, and 12 monomer units are abundant. The average molecular weight [2] based on the melting point of a camphor solution was 616 or about 9 units.

Polyxylylene seems to break at random into fragments containing up to 9 monomer units. The range of molecular weights is entirely consistent with the average molecular weight, 661 , of the nonvolatile 
fraction. An interesting point, however, is that it has been assumed that polyxylylene actually degrades into monomer and dimer units and that these repolymerize on condensation [6]. The present experiment gives no support to this theory, for degradation products are evaporated at pressures below $10^{-4} \mathrm{~mm}$, and molecular interaction is negligible.

The experiments with polyphenyl indicate that it does not degrade by breaking into shorter chains but loses hydrogen and carbonizes. A published research [5] on perfluoropolyphenyl shows that it too degrades by carbonizing. Low polymers with up to 11 rings evaporate without degradation, and the same upper limit is found for both the hydrocarbon and the fluorocarbon.

The upper limits of molecular weights observed in mass spectra of four of the polymers are listed in table 7. These limits are presumably set by the consideration that heavier molecules will degrade at the evaporation temperature. A variable intensity factor also enters into consideration. The aromatic polymers are favored in this respect, as their molecule ions are relatively abundant. These are the heaviest hydrocarbons ever reported in mass spectra. The simple recurring pattern of these polymers leaves little doubt as to the molecular formulas of the heavy molecules. The polyvinyl chloride product is an exception in that the degradation product is hopelessly complicated.

Three different types of experiments have been reported: (1) the direct evaporation of degradation products into the mass spectrometer, (2) the reevaporation of degradation products recovered in a separate experiment (table 4), (3) the evaporation of low polymers without degradation (table 6). In the second and third types of experiments the complicated mixture is fractionated as the temperature is gradually increased, and this simplifies the resulting spectra. The results afford a basis for
TABLE 7. Upper mass limits of polymer mass spectra

\begin{tabular}{|c|c|c|c|}
\hline Polymer & Temperature & Ion & Mass \\
\hline $\begin{array}{l}\text { Polyethylene } \\
\text { Rubber } \\
\text { Polyxylylene } \\
\text { Polyphenyl }\end{array}$ & $\begin{array}{l}{ }^{\circ} C \\
386 \\
264 \\
310 \\
390\end{array}$ & $\begin{array}{l}\mathrm{C}_{49} \mathrm{H}_{96} \\
\mathrm{C}_{80} \mathrm{H}_{127} \\
\mathrm{C}_{72} \mathrm{H}_{71} \\
\mathrm{C}_{66} \mathrm{H}_{46}\end{array}$ & $\begin{array}{r}684 \\
1,087 \\
935 \\
838\end{array}$ \\
\hline
\end{tabular}

observing the distribution of molecular weights in the material. Results are not quantitative, as there is no possibility of calibrating the sensitivity of the mass spectrometer in terms of pure chemical compounds. However, these experimental results are, in general, consistent with values of the average molecular weight of the degradation products as measured by the NBS Polymer Structure Section. There is no evidence that the condensed degradation products repolymerize to form larger molecules, but results on the degradation of rubber are inconclusive on this point and deserve further study.

\section{References}

[1] S. L. Madorsky, S. Straus, Dorothy Thompson, and Laura Williamson, J. Research NBS 42, 499 (1949) RP1989.

[2] S. Straus and S. L. Madorsky, J. Research NBS 50, 165 (1953) RP2405.

[3] S. L. Madorsky and S. Straus, J. Research NBS 53, 361 (1954) RP2553.

[4] Paul Bradt, Vernon H. Dibeler, and Fred L. Mohler, J. Research NBS 50, 201 (1953) RP2410.

[5] Paul Bradt and Fred L. Mohler, Anal. Chem. 27, 875 (1955)

[6] S. L. Madorsky and S. Straus, J. Research NBS 55, 223 (1955) RP2624.

[7] Symposium on polymer degradation mechanisms, NBS Circular 525 (1953).

[8] American Petroleum Institute Catalog of Mass Spectral Data.

WAshington, July 26, 1955. 